\title{
Komputasional Derivat Penisilin yang Tahan Asam dan Tahan Enzim Beta Laktamase
}

\author{
Computational Peniclilin Derivative That is Resistant to Acid and Beta \\ Laktamase Enzyme
}

\author{
Hari Purnomo ${ }^{*}$, Intan Setyorini $\mathrm{K}^{2}$ \\ 1. Lab. Kimia Medisinal Fakultas Farmasi UGM; 2. Mahasiswa S1 Fakultas Farmasi UGM \\ Corresponding author: Hari Purnomo: Email: hapepeha@yahoo.com
}

\begin{abstract}
ABSTRAK
Penisilin adalah antibiotika yang masih banyak digunakan untuk mengatasi infeksi. Beberapa derivat penisilin diketahui mempunyai sifat tahan asam seperti penisilin $\mathrm{V}$, ampisilin, amoksisilin dan metisilin. Derivat penisilin yang lain mempunyai sifat tahan terhadap enzim beta laktamase seperti metisilin, nafsilin dan kloksasilin. Kimia komputasi dapat menjelaskan mengapa hal tersebut dapat terjadi.Gugus yang bertanggung jawab terhadap proses terjadinya hidrolisa oleh asam dan peruraian oleh enzim dapat dihitung kerapatan elektronnya, sehingga dapat difahami mengapa derivat yang satu tahan asam dan yang lain tahan terhadap enzim beta laktamase. Penelitian dilakukan dengan mengoptimasi masing masing molekul menggunakan metoda semi empiris PM3, dengan gradien 0,01 dan menghitung kerapatan elektron pada karbonilnya. Dari hasil penelitian dapat disimpulkan bahwa pada penisilin yang tahan asam, kerapatan elektron atom 0 karbonil amida sebesar $-0,335$ pada penisilin $V,-0,333$ pada metisilin, $-0,316$ pada ampisilin , -0,315 pada amoksisilin, keempatnya kurang nukleofil dibanding kerapatan elektron atom 0 amida pada benzyl penisilin yang tidak tahan asam sebesar $-0,347$. Untuk penisilin yang tahan enzim beta laktamase dapat disimpulkan bahwa kerapatan elektron atom $\mathrm{C}$ karbonil lactam pada nafsilin $+0,272$, kloksasilin $+0,270$, metisilin $+0,269$ kurang elektrofil dibanding penisilin yang tidak tahan enzim beta laktamase sebesar $+0,280$.
\end{abstract}

Kata kunci: penisilin, tahan asam, tahan enzim, komputasi

\begin{abstract}
Penicillin is an antibiotic that is still widely used to treat infections. Some penicillin derivatives are known to have acid resistance properties such as penicillin $\mathrm{V}$, ampicillin, amoxicillin and methicillin. Other penicillin derivatives have resistance to beta lactamase enzymes such as methicillin, nafsilin and cloxacillin. Computational chemistry can explain why this can occur. Groups responsible for the hydrolysis process by acids and decomposition by enzymes can be calculated elektron density, so it can be understood why derivatives that are acid resistant and others are resistant to the beta lactamase enzyme. The study was conducted by optimizing each molecule using the PM3 semi-empirical method, with a gradient of 0.01 and calculating the elektron density in the carbonyl. From the results of the study it can be concluded that the acid-resistant penicillin, elektron density of the 0 carbonyl amide at -0.335 in penicillin $\mathrm{V},-0.333$ in methicillin, -0.316 in ampicillin, 0.315 in amoxicillin, the four less nucleophiles than the elektron density of the 0 amide at Benzyl penicillin which is not acid resistant is $-0,347$. For penicillin which is resistant to beta laktamase, it can be concluded that the elektron density of C carbonyl lactam in nafsilin +
\end{abstract}


0.272 , cloxacillin +0.270 , methicillin +0.269 is less electrophile than penicillin which is not resistant to the beta laktamase enzyme +0.280 .

Keywords: penicillin, acid resistance, enzyme resistance, computation

\section{PENDAHULUAN}

Penisilin adalah antibiotika yang masih banyak digunakan untuk mengatasi infeksi. Bensil Penisilin (Penisilin G) adalah peniisilin yang tidak tahan asam dan tidak tahan enzim beta laktamase. Beberapa derivat penisilin diketahui mempunyai sifat tahan asam seperti penisilin V, ampisilin, amoksisilin dan metisilin.<smiles>[R]C(=O)N[C@@H]1C(=O)N2SC(C)(C)[C@@H](C(=O)O)[C@H]12</smiles><smiles>[R]=[Ni]</smiles>

Struktur Bensil Penisilin (Penisilin G)<smiles>[R]C(=O)N[C@@H]1C(=O)N2[C@@H](C(=O)O)C(C)(C)S[C@H]12</smiles><smiles>[R]=C1C=CC=C=C=C1OC</smiles>

Struktur Penisilin V<smiles>[R]C(=O)N[C@H]1C(=O)N2[C@@H]1S[C@@](C)(C(=O)O)[C@H]2C</smiles><smiles>[R]=C1C=CC=C=C1C(C)N</smiles>

Struktur Ampisilin<smiles>[R]C(=O)N[C@@H]1C(=O)N2[C@@H]1[C@H](C(=O)O)C2(C)C</smiles>

$\mathbf{R}=$<smiles>COc1cccc(OC)c1C</smiles>

Struktur metisilin

Derivat penisilin yang lain mempunyai sifat tahan terhadap enzim beta laktamase seperti metisilin, nafsilin dan kloksasilin. 
Penisilin G yang tidak tahan asam akan mengalami hidrolisa oleh asam sebagai berikut :

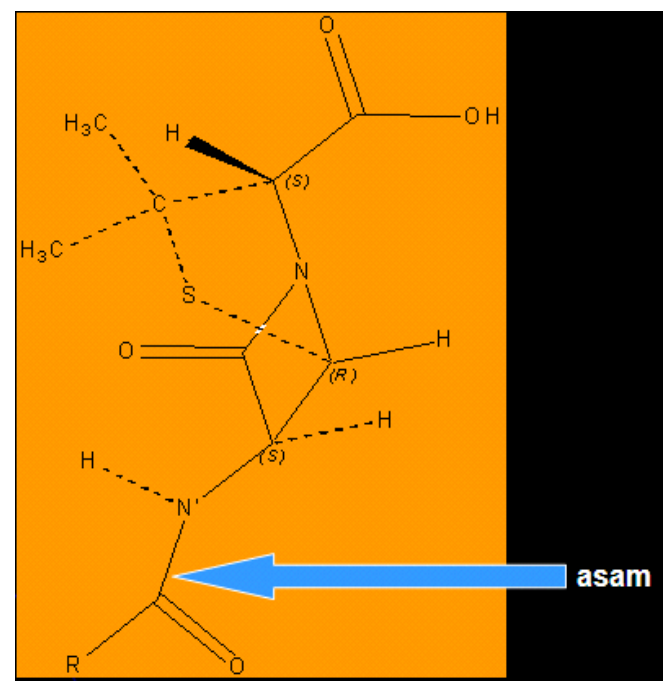

Mengikuti mekanisme :

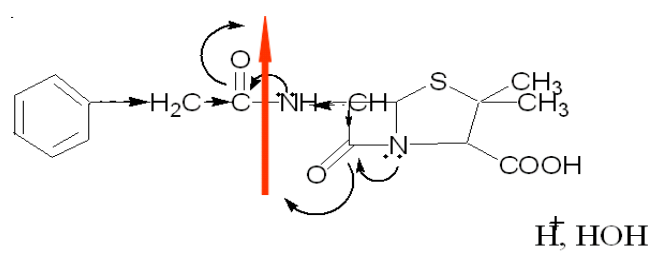

Dalam Suasana Asam: Nukleofil yang paling aktif akan menyerang proton: 0 karbonil yang paling nukleofil antara oksigen dari karbonil amida dan karbonil laktam.

Derivat penisilin yang lain mempunyai sifat tahan terhadap enzim beta laktamase seperti metisilin, nafsilin dan kloksasilin.

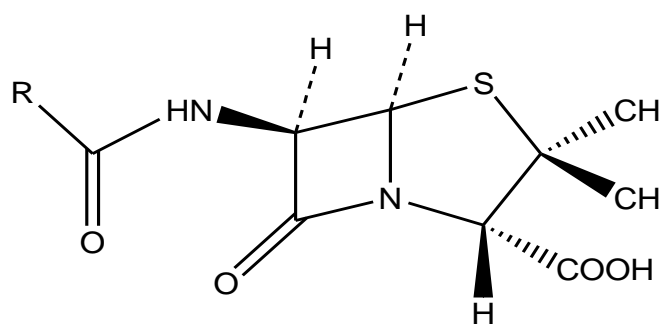

$\mathbf{R}=$<smiles>COc1cccc(OC)c1C=Cc1ccccc1</smiles>

Struktur metisilin<smiles>[R]C(=O)N[C@@]1([2H])C(=O)N2[C@H](C(=O)O)C(C)(C)S[C@@H]21</smiles><smiles>[R]=C1C=Cc2ccc(OC)c(C)c2C=C1</smiles>

Struktur Nafsilin<smiles>[R]C(=O)N[C@H]1C(=O)N2[C@H]1SC(C)(C)[C@@H]2C(=O)O</smiles><smiles>[R]c1cccc(C2NOCC2C)c1Cl</smiles>

Struktur kloksasilin 
Penisilin G yang tidak tahan enzim atau basa akan mengalami hidrolisa oleh enzim atau basa sebagai berikut:

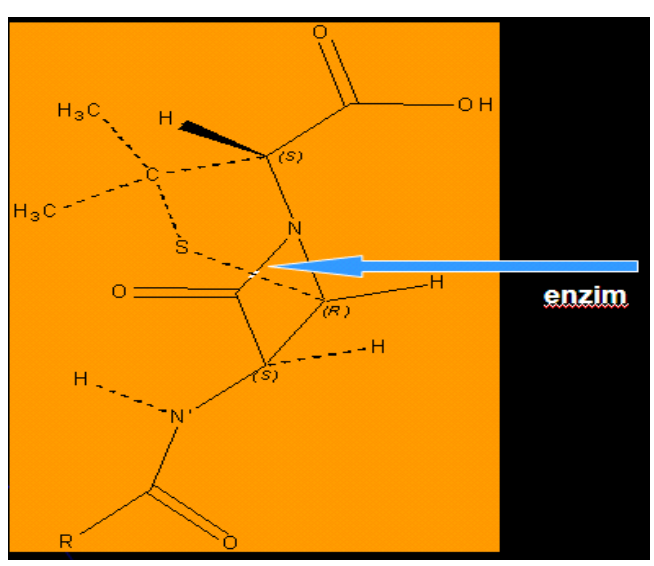

Adapun mekanismenya sebagai berikut:

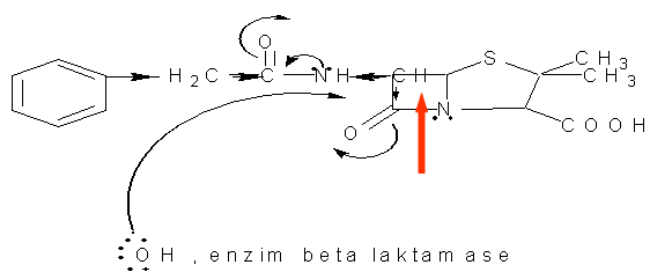

Dalam Suasana Basa (Enzim ß laktamase): Elektron dari $\mathrm{O}$ atau $\mathrm{N}$ dari basa atau enzim akan menyerang karbon yang paling elektrofi. Disini ada dua karbon karbonil laktam dan karbonil amida. Dengan mengetahui karbon mana yang paling elektrofil maka akan dapat dijelaskan secara komputasional mengapa suatu derivate penisili tahan terhadap enzim beta laktamase.

\section{METODOLOGI}

\section{Alat}

Laptop dengan spesifikasi:

1. Windows 10 Pro 64 -bit (10.0, build 15063)

2. Asustek Computer, Intel (R) Core (TM)i3-6006U

3. CPU @ $2.00 \mathrm{GHz}$ (4 CPUs) $-2.0 \mathrm{GHz}$, Memory 4096MB RAM

4. HyperChem 8

\section{Bahan}

Struktur penisilin V, ampisilin, amoksisilin, metisilin, metisilin, nafsilin dan kloksasilin.

\section{Cara Kerja}

Perhitungan kerapatan elektron derivat penisilin

Dengan Program HyperChem 8 gambar kerangka struktur dua dimensi derivat penisilin. Tambahkan atom Hidrogen untuk melengkapi strukturnya. Rubah struktur dua dimensi menjadi struktur tiga dimensi, edit letak atomnya jika diperlukan (cis atau trans). Optimasi geometrikan senyawa tersebut menggunakan metoda Moleculer Mechanic $\left(M^{+}\right)$dengan algoritma Polak- Ribeire, isikan 0,01 pada RMS (Root Mean Square) gradient of sebagai batas konvergensi. Tekan $O K$. Tunggu sampai proses optimasi selesai (Ditandai dengan munculnya tanda YES). Setelah teroptimasi dengan $\mathrm{MM}^{+}$, lanjutkan dengan metode AM1 (Austin Model 1) untuk mengoptimasi geometri molekul penisilin tersebut. Gunakan algoritma Polak- Ribeire, isikan 0,01 pada RMS gradient of sebagai batas konvergensi. Tekan $O K$. Tunggu sampai proses optimasi selesai (Ditandai dengan munculnya tanda $Y E S$ ). Untuk menyimpan proses optimasi dalam notepad: klik Star log Simpan file dengan ekstensi. Log, kemudian klik single point dalam menu compute. Setelah selesai proses penyimpanan, tekan Stop log pada menu File. Buka direktori tempat menyimpan File Log. Terakhir, buka File Notepad, catat dan simpan nilai kerapatan elektron atom atom oksigen dan karbon pada gugus karbonil.

\section{Analisa Data}

Kerapatan elektron atom 0 karbonil amida menentukan apakah suatu derivat penisilin tahan terhadap asam atau tidak tahan terhadap asam, sedangkan kerapatan elektron karbon karbonil laktam menentukan apakah derivat penisilin tahan 
Tabel I. Perbedaan kerapatan electron atom 0 pada penisilin tahan asam dan tidak tahan asam

\begin{tabular}{clc}
\hline Senyawa tidak tahan asam & Senyawa tahan asam & Kerapatan elektron atom 0 \\
\hline Benzil Penisilin & & $-0,347$ \\
& Penisilin V & $-0,335$ \\
& Ampisilin & -0.316 \\
& Amoksisilin & $-0,315$ \\
& metisilin & $-0,333$ \\
\hline
\end{tabular}

Tabel II. Perbedaan kerapatan elektron atom $C$ pada penisilin tahan enzim $\beta$ laktamase dan tidak tahan enzim $\beta$ laktamase

\begin{tabular}{ccc}
\hline $\begin{array}{c}\text { Senyawa tidak tahan } \\
\text { enzim } \boldsymbol{\beta} \text { laktamase }\end{array}$ & $\begin{array}{c}\text { Senyawa tahan enzim } \boldsymbol{\beta} \\
\text { laktamase }\end{array}$ & Kerapatan elektron atom C \\
\hline Benzil penisilin & Metisilin & $+0,280$ \\
& Nafsilin & $+0,269(<0,280)$ \\
& Kloksasilin & $+0,272(<0,280)$ \\
& & $+0,270 \quad(<0,280)$ \\
\hline
\end{tabular}

terhadap enzim beta laktamase atau tidak tahan terhadap enzim beta laktamase.

\section{HASIL DAN PEMBAHASAN \\ Pembahasan Tabel I}

Mekanisme terjadinya peruraian penisilin yang tidak tahan asam sebagai berikut:

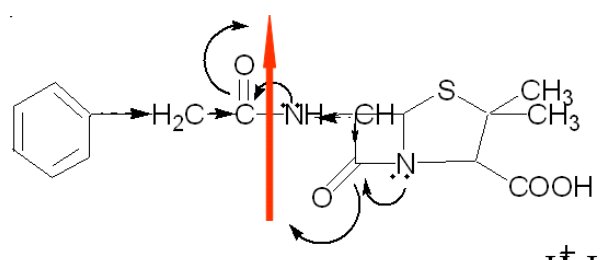

Ḧ, $\mathrm{HOH}$

Atom oksigen akan mendonorkan pasangan elektron ke proton (asam), sehingga ikatan phi akan terdelokalisasi ke oksigen, akibatnya $\mathrm{C}$ karbonil amida akan bermuatan positif. Adanya muatan positif atom $\mathrm{C}$ tersebut akan memutus ikatan $\mathrm{C}-\mathrm{N}$. Sedangkan pada penisilin yang tahan asam (penisilin V, ampisilin, amoksisilin, metisilin) terlihat bahwa kerapatan elektron atom 0 karbonil amida kurang nukleofil dibandingkan pada bensil penisilin.

\section{Pembahasan Tabel II}

Terjadinya peruraian penisilin yang tidak tahan enzim $\beta$ laktamase adalah sebagai berikut :

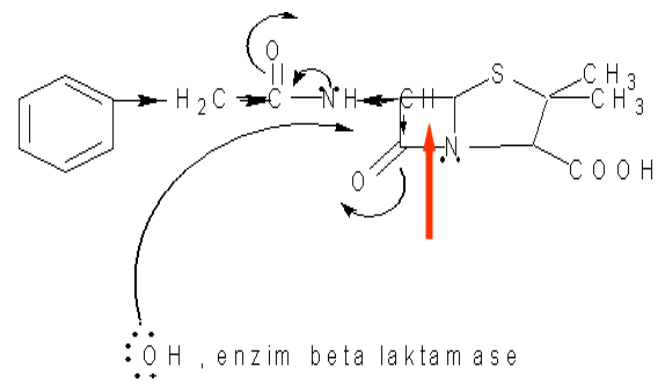

Dalam Suasana Basa (Enzim ß laktamase): Elektron dari $\mathrm{O}$ atau $\mathrm{N}$ dari basa atau enzim akan menyerang karbon yang paling elektrofil. Disini ada dua karbon karbonil laktam dan karbonil amida. Berdasarkan kimia komputasi maka C karbonil lactam yang lebih elektrofil (Hyperchem, PM3: + +0,280 dibanding $+0,260$ ), karena C karbonil laktam kurang mendapat induksi elektron dari sekitarnya dibanding C karbonil amida yang mendapat induksi elektron dari benzyl. 
Dari hal tersebut diatas terlihat bahwa atom kunci untuk terjadinya peruraian oleh enzim $\beta$ laktamase adalah atom c lactam. Dari table terlihat bahwa kerapatan elektron C lactam dari benzyl penisilin paling elektrofil disbanding penisilin yang tahan terhadap enzim $\beta$ laktamase yaitu metisilin, nafsilin, dan kloksasilin. Dengan demikian kunci agar penisilin tahan terhadap enzim $\beta$ laktamase adalah kerapatan elektron atom $C$ laktam harus kurang elektrofil disbanding benzyl penisilin.

\section{KESIMPULAN}

Penisilin yang tahan asam, mempunyai kerapatan elektron atom 0 karbonil amida sebesar $-0,335$ pada penisilin $\mathrm{V},-0,333$ pada metisilin, $-0,316$ pada ampisilin, $-0,315$ pada amoksisilin, keempatnya kurang nukleofil dibanding kerapatan elektron atom $\mathrm{O}$ amida pada benzyl penisilin yang tidak tahan asam sebesar $-0,347$. Untuk penisilin yang tahan enzim beta laktamase dapat disimpulkan bahwa kerapatan elektron atom $\mathrm{C}$ karbonil lactam pada nafsilin $+0,272$, kloksasilin $+0,270$, metisilin $+0,269$ kurang elektrofil dibanding penisilin yang tidak tahan enzim beta laktamase sebesar $+0,280$.

\section{DAFTAR PUSTAKA}

Krauss K, editor (1999). "Yale-New Haven Hospital Annual Report" (PDF). New Haven: Yale-New Haven Hospital.

Mutschler, E., 1991, Dinamika Obat, diterjemahkan oleh Mathilda, B.W, dan Anna, S.R., Edisi 5, 9-12, 93, 572, Penerbit ITB Bandung.

Madigan, MT; Martinko JM, Dunlap PV, Clark DP. Brock Biology of Microorganisms (12 ed.). San Francisco: Pearson Benjamin Cummings.p. 795. ISBN 9780321536 150.

Pelczar, Jr., MT; E.C.S. Chan. Dasar-dasar Mikrobiologi (1 ed.). Jakarta: UI Press. p. 517.

Rossi S, editor, ed. (2006). Australian Medicines Handbook. Adelaide: Australian Medicines Handbook. ISBN 0-9757919-2-3.

Saxon, W. (1999-06-09). "Anne Miller, 90, first patient who was saved by penicillin". The New York Times. Diarsipkan dari versi asli tanggal 2012-05-29.

Siswandono dan Soekardjo B , 2000, Kimia Medisinal', jilid 2, Airlangga University Press, Surabaya.

Silverthorn, DU. (2004). Human physiology: an integrated approach. (3rd ed.). 